Catatan Penelitian

\title{
Kadar Air, Tanin, Warna dan Aroma Off-Flavour Minuman Fungsional Daun Sirsak (Annona Muricata) dengan Berbagai Konsentrasi Jahe (Zingiber Officinale)
}

Moisture Content, Tannin, Colour and Off-flavour Aroma of Functional Drink Made from Soursop Leaves (Annona muricata) using Several Concentration of Ginger (Zingiber officinale)

Yasmine Setya Adilla Mawardi, Yoyok Budi Pramono, Bhakti Etza Setiani

Program Studi Teknologi Pangan, Fakultas Peternakan dan Pertanian, Universitas Diponegoro, Semarang

*Korespondensi dengan author (etz_16@yahoo.com)

Artikel ini dikirim pada tanggal 8 April 2016 dan dinyatakan diterima tanggal 15 Mei 2016. Artikel ini juga dipublikasi secara online melalui

www.jatp.ift.or.id. Hak cipta dilindungi undang-undang. Dilarang diperbanyak untuk tujuan komersial.

Diproduksi oleh Indonesian Food Technologists® (C2016

\begin{abstract}
Abstrak
Penelitian ini bertujuan mengevaluasi karakteristik kadar air, tanin, warna dan aroma off-flavour produk minuman fungsional daun sirsak dengan konsentrasi jahe yang ditambahkan. Desain penelitian yang digunakan adalah rancangan acak lengkap (RAL) dengan perlakuan penambahan konsentrasi jahe pada minuman fungsional daun sirsak sebesar $0 \%, 10 \%, 20 \%, 30 \%$, dan $40 \%$. Ulangan dilakukan sebanyak 4 kali, dengan parameter kadar air, tanin, serta warna dan aroma off-flavour sebagai uji sensoris. Hasil penelitian menunjukkan bahwa kadar air produk berkisar antara 7,67-10,97\%, kadar tanin berkisar antara 1,17-2,35 mg/L, warna dengan skor 2,45-3,55, dan aroma off-flavour dengan skor 2,22-3,15. Hal ini menunjukkan bahwa terjadi peningkatan nilai kadar air seiring dengan meningkatnya konsentrasi jahe yang ditambahkan, sedangkan kadar tanin semakin turun seiring dengan tingginya konsentrasi jahe yang ditambahkan. Terjadi penurunan kesukaan konsumen pada atribut warna dan peningkatan kesukaan panelis terhadap aroma off-flavour seiring dengan tingginya konsentrasi jahe yang ditambahkan. Kesimpulannya jahe dapat digunakan sebagai bahan tambahan pada pembuatan minuman fungsional daun sirsak hingga konsentrasi $40 \%$. Jahe dapat digunakan sebagai perisa alami dan peningkat kualitas berupa kadar tanin minuman fungsional daun sirsak.
\end{abstract}

Kata kunci : minuman fungsional, daun sirsak, jahe

\begin{abstract}
The study aimed to evaluate the characteristics of moisture content, tannin content, colour, and off-flavour aroma with several concentrations of ginger which were added to functional drink made from soursop leaves (Annona muricata Linn.) The research design used were a completely randomized design with treatments such as concentration of ginger which is added to the soursop leaves functional drink, those were: $0 \%, 10 \%, 20 \%, 30 \%$ and $40 \%$. Each treatment was repeated 4 times, with parameters measured were moisture content, tannin content, and organoleptic test such as color and off-flavour aroma. The results has a moisture content products ranging from 7,67-10,97\%, tannin levels ranged from 1,17 mg/L-2,35 mg/L, colour has score on 2,45-3,55, and off-flavor aroma has score on 2,22-3,15. On testing soursop leaves functional drink increase in water content along with the increasing concentration of ginger added, while the tannin content of functional drink decrease with the high concentration of ginger added. There was a decreasing preferences by panelist in colour attribute and increasing preferences by panelist in off-flavour aroma along with the increasing concentration of ginger added. In conclusion, ginger can be used as additives in the manufacture of soursop leaves functional drink up to $40 \%$ ginger concentration. Ginger can be used as a natural flavor and enhancing the tannin contents of soursop leaves functional drink.
\end{abstract}

Keywords : functional drink, soursop leaves, ginger

\section{Pendahuluan}

Penelitian ini bertujuan mengevaluasi karakteristik kadar air, tanin, warna dan aroma offflavour produk minuman fungsional daun sirsak dengan konsentrasi jahe yang ditambahkan. Pangan fungsional adalah makanan yang mempunyai khasiat kesehatan tertentu terhadap tubuh di samping zat gizi yang dikandungnya. Pangan fungsional memiliki fungsi fungsi fisiologis seperti mengatur daya tahan tubuh, menangkal radikal bebas, mengatur ritmik kondisi fisik, mencegah penuaan, dan mencegah penyakit yang berkaitan dengan makanan. Salah satu bentuk pangan fungsional adalah dalam bentuk cairan atau minuman. Minuman fungsional dapat berasal dari bahan alami yang mudah ditemukan sehari-hari, salah satunya adalah berasal dari daun sirsak. Tanaman sirsak (Annona muricata Linn.) merupakan tanaman yang kaya zat gizi karena daunnya mengandung senyawa steroid/terpenoid, flavonoid, kumarin, alkaloid, tanin, kalsium, karbohidrat, fosfor, vitamin A, vitamin B, vitamin C, fitosterol, kalsium oksalat, dan alkaloid murisine (Muizuddin dan Zubaidah, 2015) serta 
senyawa aktif acetogenins yang efektif melawan sel kanker.

Pengolahan daun sirsak menjadi produk minuman fungsional dilakukan dengan menyajikannya dalam bentuk celup. Minuman celup merupakan produk olahan minuman yang dikemas dalam kemasan kantung (bag) yang terbuat dari filter paper dan dapat disajikan secara cepat dan instan jika dibandingkan dengan menggunakan daun utuh. Air seduhan daun sirsak memiliki rasa yang kurang enak dan aroma yang langu, sehingga air seduhan tersebut tidak terlalu disukai oleh sebagian orang. Oleh karena itu, diperlukan bahan tambahan yang akan memberikan rasa tertentu pada minuman fungsional daun sirsak sekaligus dapat menambah manfaat bagi tubuh, salah satu bahan perisa yang dapat ditambahkan ke dalam minuman fungsional daun sirsak adalah jahe. Jahe memiliki cita rasa dan aroma yang kuat, serta memberikan efek menghangatkan tubuh yang dapat menjadi daya tarik bagi masyarakat untuk lebih mengonsumsinya.

Parameter yang diuji dalam pada pembuatan minuman fungsional daun sirsak terdiri dari kadar air, tanin, organoleptik warna dan off-flavour. Komposisi air pada bahan pangan terdiri dari air bebas dan air terikat. Kadar air dapat mempengaruhi suhu atau lama pengeringan bahan pangan. Kadar air yang cukup tinggi dapat mempengaruhi daya tahan terhadap serangan mikroorganisme, sehingga bahan tersebut mudah rusak dan tidak tahan dalam penyimpanannya (Winarno, 2002). Oleh karena itu, perlu dilakukan suatu proses pengeringan agar mengurangi sebagian air yang terkandung dalam bahan sehingga dapat memperpanjang masa simpan produk.

Tanin merupakan senyawa antioksidan biologis yang tersusun dari senyawa fenolik yang sukar dipisahkan dan sukar mengkristal. (Desmiaty et al., 2008). Tanin mempengaruhi rasa pada bahan makanan seperti teh menjadi sepat dan buah-buahan menjadi asam karena tanin termasuk dalam senyawa flavour sehingga menimbulkan rasa tertentu dalam makanan. Makanan yang mengandung tanin memiliki rasa yang sepat karena terjadi reaksi pembentukan kompleks antara tanin dan protein di dalam mulut (Tandi, 2010).

Warna merupakan suatu sifat bahan yang dianggap berasal dari penyebaran spektrum sinar (Kartika et al., 1988). Penilaian terhadap parameter warna dilakukan dengan melihat secara visual minuman yang disajikan. Selama proses pengolahan terjadi proses perubahan katekin menjadi senyawasenyawa yang lebih sederhana yang diduga menjadi senyawa-senyawa polifenol flavonoid yang memberi warna pada air seduhan minuman. Aroma off-flavour merupakan bau dan atau rasa produk yang dinilai oleh panelis menyimpang dari normal. Terjadinya off-flavour pada suatu bahan pangan menandakan bahwa telah terjadi penurunan kualitas pada bahan pangan yang akan mempengaruhi penerimaan konsumen. Faktor utama yang mengakibatkan terjadinya penurunan mutu atau kerusakan pada produk pangan yaitu massa oksigen, uap air, cahaya, mikoorganisme, kompresi atau bantingan, dan bahan kimia toksik atau off-flavour (Herawati, 2008).

Pengujian kadar air dalam minuman berperan untuk menentukan mutu karena menentukan masa simpan produk. Tanin merupakan senyawa antinutrisi yang dapat menghambat penyerapan zat besi dalam tubuh. Penambahan jahe pada minuman fungsional daun sirsak diharapkan dapat menurunkan kadar tanin pada produk. Pengujian sifat organoleptik berperan dalam menentukan penerimaan konsumen terhadap produk. Warna air rebusan daun sirsak adalah hijau kekuningan dan tidak terlalu gelap, sehingga pada penambahan berbagai konsentrasi jahe ke dalam minuman fungsional daun sirsak diharapkan dapat mempengaruhi warna yang dihasilkan menjadi kecoklatan menyerupai warna teh. Perbedaan konsentrasi jahe yang ditambahkan ke dalam minuman fungsional daun sirsak diharapkan makin meningkatkan aroma harum pada minuman karena dipengaruhi oleh senyawa zingiberene dan zingiberol yang semakin meningkat.

\section{Materi dan Metode \\ Materi}

Alat yang digunakan dalam pembuatan minuman fungsional daun sirsak adalah oven, mortar, blender, dan timbangan analitik, sedangkan alat yang digunakan dalam pengujian karakteristik minuman fungsional daun sirsak adalah spektrofotometer UV-VIS, tabung reaksi, oven, desikator, cawan porselin, tang penjepit, tip biru, vortex, mikropipet, pipet tetes, beker glass $250 \mathrm{ml}$, alatalat gelas untuk analisis, dan kertas kuisioner. Bahan yang digunakan dalam pembuatan minuman fungsional daun sirsak ini adalah daun sirsak, air, jahe, dan kantong teh celup, sedangkan bahan yang digunakan dalam pengujian karakteristik minuman fungsional daun sirsak ini terdiri dari aquabidestilat, pereaksi Folin Denis, $\mathrm{Na}_{2} \mathrm{CO}_{3}$ jenuh, dan aquades.

\section{Metode}

Penelitian berlangsung pada bulan OktoberDesember 2015. Penelitian meliputi proses pembuatan minuman fungsional daun sirsak dan analisa karakteristik minuman fungsional daun sirsak yang meliputi kadar air, kadar tanin, organoleptik warna, dan aroma off-flavour.

\section{Proses Pembuatan Minuman Fungsional Daun Sirsak}

Pengolahan daun sirsak menjadi minuman dilakukan menggunakan metode pengolahan teh hijau yang terdiri dari proses pemetikan daun, pelayuan, penggulungan, dan pengeringan. Proses pemetikan daun dilakukan dengan pemilihan dan pemisahan daun sirsak dari rantingnya. Daun sirsak dicuci bersih dan disortasi, setelah itu dilakukan proses pelayuan dengan suhu $70^{\circ} \mathrm{C}$ selama 4 menit dan didinginkan selama 5 menit. Proses penggulungan dilakukan dengan telapak tangan. Setelah digulung dilakukan proses pengeringan dengan suhu $50^{\circ} \mathrm{C}$ selama 150 menit. Selanjutnya dilakukan proses penggilingan daun menggunakan blender dan proses pengayakan menggunakan 
pengayak ukuran 20 mesh dan dimasukkan ke dalam kantung celup. Pengolahan jahe menjadi jahe bubuk dilakukan dengan pembersihan dan pencucian rimpang jahe dan pengirisan jahe dalam bentuk tipis-tipis. Setelah itu dilakukan proses pengeringan dengan menggunakan Cabinet dryer dengan suhu $50^{\circ} \mathrm{C}$ selama 5 jam. Setelah kering, jahe dihaluskan menggunakan blender kering, dan pengayakan ukuran mesh 20 dan jahe bubuk dapat dimasukkan ke dalam kantong celup. Perbandingan komposisi minuman fungsional daun sirsak ditunjukkan pada Tabel 1.

Pengujian mutu minuman fungsional daun sirsak dengan uji kadar air metode oven (Legowo et al., 2005), uji kadar tanin (Andriyani et al., 2010), dan uji organoleptik dengan atribut warna air seduhan dan aroma off-flavour menggunakan skor 1-5 yaitu skor $1=$ sangat tidak suka, skor $2=$ tidak suka, skor $3=$ netral, skor $4=$ suka, skor 5 = sangat suka.

\section{Analisis Data}

Data hasil pengukuran kadar air yang diperoleh dianalisis uji pengaruh menggunakan Anova (Analysis ofVarian) pada taraf signifikansi $5 \%$. Data kadar tanin dianalisis secara deskriptif menurut data hasil pengujian yang diperoleh untuk mengetahui secara langsung pengaruh perlakuan terhadap parameter yang diamati. Data hasil pengujian organoleptik dianalisis dengan menggunakan uji Kruskal-Wallis pada taraf 5\% (Kartika et al., 1988).

\section{Hasil dan Pembahasan}

Hasil nilai kadar air minuman fungsional daun sirsak dengan berbagai konsentrasi penambahan jahe berkisar antara 7,67\%-10,97\% dengan rata-rata kadar air masing-masing perlakuan dapat dilihat pada Tabel 2. Nilai rata-rata kadar air minuman fungsional daun sirsak dengan penambahan jahe secara umum telah memenuhi standar mutu kadar air yang ditetapkan dari SNI 01-4324-1996 menurut Badan Standarisasi Nasional (1996), yakni maksimal 10\%. Hasil uji statistik menyatakan bahwa data yang diperoleh signifikan sehingga dapat disimpulkan bahwa konsentrasi penambahan jahe berpengaruh sangat nyata terhadap kadar air minuman. Berdasarkan hasil pengujian kadar tanin pada minuman daun sirsak menggunakan berbagai konsentrasi penambahan jahe menunjukkan bahwa kadar tanin terbesar terdapat pada minuman daun sirsak dengan penambahan jahe sebesar $0 \%$ yaitu dengan kadar tanin sebesar $2,35 \mathrm{mg} / \mathrm{L}$ dan kadar tanin terendah terdapat pada minuman daun sirsak dengan penambahan jahe sebesar $30 \%$ yaitu dengan kadar tanin sebesar $1,17 \mathrm{mg} / \mathrm{L}$.

\section{Kadar Air}

Berdasarkan hasil pengujian kadar air pada minuman fungsional daun sirsak menggunakan berbagai konsentrasi penambahan jahe menunjukkan bahwa semakin besar konsentrasi jahe yang ditambahkan maka akan semakin besar pula kadar air minuman fungsional yang dihasilkan. Kadar air minuman fungsional yang meningkat seiring dengan meningkatnya konsentrasi jahe yang ditambahkan disebabkan karena jahe kering memiliki kadar air yang tinggi sehingga mengakibatkan bertambahnya nilai kadar air pada minuman fungsional daun sirsak. Hal ini sesuai dengan pendapat Eze dan Agbo (2011) yang menyatakan bahwa jahe kering mengandung minyak esensial sebesar $1-3 \%$, oleoresin sebesar $5-10 \%$, pati sebesar $50-55 \%$, dan kadar air sebesar $7-12 \%$ serta mengandung protein, serat, lemak, dan abu dalam jumlah yang kecil.

\section{Kadar Tanin}

Hasil pengujian kadar tanin di antara minuman fungsional daun sirsak dengan penambahan jahe konsentrasi 0\%-40\% memiliki selisih yang sedikit pada antar perlakuannya, hal itu disebabkan karena perlakuan yang diberikan berupa perbedaan konsentrasi jahe yang ditambahkan tidak mempengaruhi tanin pada minuman fungsional daun sirsak karena jahe yang ditambahkan ke dalam minuman fungsional daun sirsak mengandung tanin dalam jumlah yang kecil sehingga penambahannya di dalam minuman fungsional daun sirsak tidak menunjukkan perubahan kadar tanin yang signifikan. Hal ini sesuai dengan pendapat Umeh et al. (2013) dan Bhargava et al. (2012) yang menyatakan bahwa kadar tanin yang terdapat pada rimpang jahe yang telah diekstrak menggunakan pelarut etanol dan metanol berapa pada tingkat kecil sampai sedang. Hal tersebut didukung oleh pendapat Ogbuewu et al. (2014) yang menyatakan bahwa pada jahe kering hanya mengandung kadar tanin sebesar $0,02 \pm 0,00 \mathrm{mg} / 100$ gram.

Salah satu faktor penyebab kadar tanin pada minuman fungsional daun sirsak dengan tingkat tertinggi berada pada minuman fungsional daun sirsak dengan konsentrasi penambahan jahe sebesar $0 \%$ dan tingkat terendah berada pada minuman fungsional daun sirsak dengan konsentrasi penambahan jahe sebesar $30 \%$ adalah karena daun sirsak berperan sebagai kontributor terbesar di dalam keseluruhan total tanin pada minuman fungsional daun sirsak. Semakin besar persentase daun sirsak yang terdapat pada minuman fungsional daun sirsak maka semakin besar pula kadar tanin dalam minuman fungsional daun sirsak tersebut. Hal ini sesuai dengan pendapat Usunobun et al. (2015) yang menyatakan bahwa daun sirsak yang diekstrak menggunakan pelarut etanol terbukti mengandung tanin. Hal ini didukung oleh pendapat Hardoko et al. (2015) yang menyatakan bahwa daun sirsak yang diolah menurut cara pengolahan teh hijau dan diseduh pada air dengan suhu $80^{\circ} \mathrm{C}$ selama 15 menit memiliki kadar tanin sebesar $5,67 \mathrm{mg} / \mathrm{L}$ dan terus meningkat seiring dengan peningkatan suhu penyeduhan dan lama waktu penyeduhan.

\section{Uji Organoleptik}

Berdasarkan hasil pengujian hedonik terhadap atribut warna minuman fungsional daun sirsak dengan berbagai konsentrasi penambahan jahe, diperoleh hasil nilai warna tertinggi terdapat pada sampel minuman 
fungsional daun sirsak dengan penambahan jahe sebesar $0 \%$ yaitu sebesar 3,55 sedangkan nilai warna terendah terdapat pada sampel minuman fungsional daun sirsak dengan penambahan jahe sebesar $40 \%$ yaitu sebesar 2,45\% dengan rata-rata skor warna masing-masing perlakuan dapat dilihat pada Tabel 3. Berdasarkan hasil pengujian hedonik terhadap atribut aroma off-flavour minuman fungsional daun sirsak dengan berbagai konsentrasi penambahan jahe, diperoleh hasil nilai kesukaan aroma off-flavour tertinggi terdapat pada sampel minuman fungsional daun sirsak dengan penambahan jahe sebesar $40 \%$ yaitu sebesar 3,15 sedangkan nilai kesukaan aroma off-flavour terendah terdapat pada sampel minuman fungsional daun sirsak dengan penambahan jahe sebesar $0 \%$ yaitu sebesar 2,22 \% dengan rata-rata kadar air masing-masing perlakuan dapat dilihat pada Tabel 3.

Tabel 1. Perbandingan Komposisi Minuman Fungsional Daun Sirsak dengan Jahe

\begin{tabular}{cccccc}
\hline Formula & 1 & 2 & 3 & 4 & 5 \\
\hline Daun Sirsak & $100 \%$ & $90 \%$ & $80 \%$ & $70 \%$ & $60 \%$ \\
\hline Jahe & $0 \%$ & $10 \%$ & $20 \%$ & $30 \%$ & $40 \%$ \\
\hline
\end{tabular}

Tabel 2. Hasil Pengujian Kadar Air dan Kadar Tanin Minuman Fungsional Daun Sirsak

\begin{tabular}{ccc}
\hline Formula & Kadar Air $(\%)$ & Kadar Tanin $(\mathrm{mg} / \mathrm{L})$ \\
\hline T0 & $7,88 \pm 0,163^{\mathrm{a}}$ & 2,35 \\
T1 & $8,19 \pm 0,074^{\mathrm{a}}$ & 1,89 \\
T2 & $8,9 \pm 2,249^{\mathrm{ab}}$ & 1,51 \\
T3 & $10,08 \pm 0,148^{\mathrm{bc}}$ & 1,17 \\
T4 & $10,70 \pm 0,233^{\mathrm{c}}$ & 1,34 \\
\hline
\end{tabular}

Keterangan: Angka yang diikuti superskrip yang sama menunjukkan tidak berbeda nyata pada taraf a 0,05

Tabel 3. Hasil Pengujian Organoleptik Minuman Fungsional Daun Sirsak

\begin{tabular}{ccc}
\hline Formula & Warna & Aroma Off-flavour \\
\hline T0 & $3,55 \pm 0,605^{\mathrm{a}}$ & $2,22 \pm 0,523^{\mathrm{a}}$ \\
T1 & $3,4 \pm 0,503^{\mathrm{ab}}$ & $2,45 \pm 0,759^{\mathrm{ab}}$ \\
T2 & $3,45 \pm 0,759^{\mathrm{ab}}$ & $3,00 \pm 0,918^{\mathrm{ab}}$ \\
T3 & $3,00 \pm 0,725^{\mathrm{b}}$ & $2,9 \pm 0,968^{\mathrm{b}}$ \\
T4 & $2,45 \pm 0,605^{\mathrm{c}}$ & $3,15 \pm 0,988^{\mathrm{c}}$
\end{tabular}

Keterangan: Angka yang diikuti superskrip yang sama menunjukkan tidak berbeda nyata pada taraf a 0,05

\section{Warna}

Berdasarkan pengujian diperoleh hasil bahwa panelis lebih menyukai warna minuman fungsional daun sirsak dengan penambahan konsentrasi jahe yang semakin kecil. Warna air seduhan minuman fungsional daun sirsak dengan perlakuan perbedaan konsentrasi jahe tersebut dapat dikatakan dipengaruhi oleh konsentrasi jahe yang ditambahkan ke dalam produk. Warna air seduhan minuman fungsional daun sirsak yang ditambah dengan berbagai konsentrasi jahe melalui perlakuan $10 \%-40 \%$ jahe berbeda nyata dengan minuman fungsional daun sirsak tanpa penambahan jahe. Perbedaan tersebut disebabkan karena warna asli seduhan jahe yang berwarna cokelat kekuningan akan menetralkan warna seduhan daun sirsak berupa cokelat kemerahan sehingga semakin besar konsentrasi jahe yang ditambahkan ke dalam minuman fungsional daun sirsak maka warna air seduhan minuman fungsional daun sirsak akan semakin terang. Hal ini sesuai dengan pendapat Muzaki dan Wahyuni (2015) yang menyatakan bahwa semakin banyak jahe yang ditambahkan pada air seduhan minuman maka semakin tinggi pula nilai kecerahannya. Hal ini didukung oleh pendapat Chasparinda et al. (2014) yang menyatakan bahwa peningkatan ekstrak jahe pada suatu minuman akan meningkatkan tingkat kecerahan minuman tersebut.

Komponen minuman fungsional daun sirsak yang mempengaruhi terbentuknya warna air seduhan pada minuman berasal dari zat-zat yang terkandung di dalam daun sirsak. Warna air seduhan daun sirsak yang berwarna kuning kegelapan berhubungan dengan kadar tanin yang terkandung di dalam daun sehingga semakin besar kadar tanin yang terkandung di dalam minuman fungsional daun sirsak maka semakin gelap pula warna air seduhan minuman fungsional daun sirsak yang dihasilkan. Nilai kecerahan air seduhan yang rendah menunjukkan bahwa terdapat sumbangan zat warna yang cukup tinggi pada komponen minuman fungsional daun sirsak. Hal ini sesuai dengan pendapat Lestari et al. (2014) yang menyatakan bahwa semakin tinggi konsentrasi tanin pada daun yang diekstrak maka semakin gelap pula warna yang akan dihasilkan. Kontributor lain yang berperan dalam pembentukan warna air seduhan minuman fungsional daun sirsak adalah theaflavin dan flavonol yang memberikan warna kuning pada seduhan. Apabila klorofil pada daun terjadi proses degradasi maka akan membuat warna minuman yang kuning menjadi lebih gelap. Hal ini sesuai dengan pendapat Chaturvedula dan Prakash (2011) yang menyatakan bahwa produk degradatif dari klorofil berupa pheophytin dan pheophorbide akan menyebabkan warna dari minuman menjadi lebih gelap. Degradasi klorofil tersebut diaktifkan oleh enzim chlorophyllase, temperatur yang tinggi, serta tingkat kelembaban yang tinggi.

\section{Aroma Off-flavour}

Aroma off-flavour merupakan aroma suatu bahan pangan yang menyimpang dari aroma normal yang menyebabkan penurunan penerimaan panelis. Aroma off-flavour tertinggi yang terdapat pada minuman fungsional daun sirsak berada pada minuman dengan perlakuan penambahan jahe sebesar $0 \%$ yaitu minuman fungsional daun sirsak yang tersusun hanya dari bahan daun sirsak. Minuman fungsional daun sirsak dengan perlakuan kontrol memiliki aroma offflavour yang tinggi karena daun sirsak memiliki aroma yang kurang sedap atau disebut dengan aroma langu dan dapat dirasakan ketika terjadi proses penyeduhan daun sirsak. Hal ini sesuai dengan pendapat Kumar et al. (2015) yang menyatakan bahwa tanaman sirsak merupakan pohon cemara kecil pada daerah tropis yang memiliki percabangan yang pendek dan lebat, memiliki tinggi sekitar 7-9 meter, serta memiliki daun yang kasar dengan bau yang tidak menyenangkan. Aroma tidak sedap atau langu pada daun sirsak berasal dari komponen volatil dari daun yang memberikan 
karakteristik khusus pada produk. Hal ini sesuai dengan pendapat Lee et al. (2013) yang menyatakan bahwa aroma tidak menyenangkan pada daun berupa aroma langu berasal dari kelompok senyawa aldehid alifatik yaitu dari senyawa volatil 3-Methyl-butanal.

\section{Kesimpulan}

Konsentrasi jahe yang ditambahkan pada minuman fungsional daun sirsak terbukti berpengaruh terhadap kadar air dan kadar tanin. Pada pengujian minuman fungsional daun sirsak menunjukkan bahwa terjadi peningkatan nilai kadar air seiring dengan meningkatnya konsentrasi jahe yang ditambahkan, sedangkan kadar tanin minuman fungsional menjadi semakin turun seiring dengan tingginya konsentrasi jahe yang ditambahkan. Minuman fungsional daun sirsak yang paling optimum berdasarkan hasil uji organoleptik adalah minuman fungsional daun sirsak dengan penambahan jahe sebesar 20\% karena memiliki warna sangat terang dan aroma off-flavour yang tidak terasa.

\section{Daftar Pustaka}

Andriyani, D., P.I. Utami, dan B.A. Dhiani. 2010. Penetapan kadar tanin daun rambutan (Nephelium lappaceum L.) secara spektrofotometri ultraviolet visibel. Pharmacy. 7: 1-11.

Badan Standarisasi Nasional. 1996. Standar Nasional Indonesia (SNI). SNI 01-4324-1996. Teh Hijau Celup. Dewan Standarisasi Indonesia, Jakarta.

Bhargava, S., K. Dhabhai, A. Batra, A. Sharma, dan B. Malhotra. 2012. Zingiber officinale : chemical and phytochemical screening and evaluation of its antimicrobial activities. Journal of Chemical and Pharmaceutical Research. 4 (1): 360-364.

Chasparinda, M.E., M.A.M. Andriani, dan Kawiji. 2014. Pengaruh penambahan jahe (Zingiber officinale R.) terhadap karakteristik fisikokimia dan organoleptik sari buah bit (Beta vulgaris L.). Jurnal Teknologi Hasil Pertanian Universitas Sebelas Maret. 3 (2): 20-27.

Chaturvedula, V.S. dan I. Prakash. 2011. The aroma, taste, color and bioactive constituents of tea. Journal of Medicinal Plant Research. 5 (11): 2110-2124.

Desmiaty, Y., H. Ratih, M.A. Dewi. dan R. Agustin. 2008. Penentuan jumlah tanin total pada daun jati belanda (Guazuma ulmifolia Lamk) dan daun sambang darah (Excoecaria bicolor Hassk.) secara kolorimetri dengan pereaksi biru prusia. Ortocarpus. 8: 106-109.

Eze, J.I. dan K.E. Agbo. 2011. Comparative studies of sun and solar drying of peeled and unpeeled ginger. American Journal of Scientific and Industrial Research. 2 (2): 136-143.

Hardoko, Y. Halim, dan S.V. Wijoyo. 2015. In vitro antidiabetic activity of "green tea" soursop leaves brew through a-glucosidase inhibition.
International Journal of PharmTech Reasearch. 8 (1): 30-37.

Herawati, H. 2008. Penentuan umur simpan pada produk pangan. Jurnal Litbang Pertanian. 27 (4): 124-130.

Kartika, B, B. Hastuti, dan W. Supartono. 1988. Pedoman Uji Inderawi Bahan Pangan. Pusat antar Universitas Pangan dan Gizi UGM, Yogyakarta.

Kumar, S.A., V. Venkatarathanamma, dan N.V. Saibabu. 2015. Phytochemical and phytotherapeutic properties of Annona squamosa, Annona reticulata and Annona muricata: a review. Asian Journal of Plant Science and Research. 5 (8): 28-33.

Lee, J., D.H. Chambers, E. Chambers, K. Adhikari, dan Y. Yoon. 2013. Volatile aroma compounds in various breewed green teas. Molecules. 18: 10024-10041.

Legowo, A. M., Nurwantoro dan Sutaryo. 2005. Analisis Pangan. Badan Penerbit Universitas Diponegoro, Semarang.

Lestari, P., S. Wijana, dan W.I. Putri. 2014. Ekstraksi Tanin dari Daun Alpukat (Persea americana Mill.) sebagai Pewarna Alami (Kajian Proporsi Pelarut dan Waktu Ekstraksi). Jurusan Teknologi Industri Pertanian Universitas Brawijaya, Malang.

Muizuddin, M. dan E. Zubaidah. 2015. Studi aktivitas antibakteri kefir teh daun sirsak (Annona muricata Linn.) dari berbagai merk teh daun sirsak di pasaran. Jurnal Pangan dan Agroindustri 3 (4): 1662-1672.

Muzaki, D. dan R. Wahyuni. 2015. Pengaruh penambahan gingger kering (Zingiber officinale) terhadap mutu dan daya terima teh herbal daun afrika selatan (Vernonia amygdalina). Jurnal Teknologi Pangan. 6 (2): 67-75.

Ogbuewu, I.P., P.D. Jiwuba, C.T. Ezeokeke, M.C. Uchegbu, I.C. Okoli, dan M.U. Iloeje. 2014. Evaluation of phytochemical and nutritional composition of ginger rhizome powder. International Journal of Agricultural and Rural Development. 17 (1): 1663-1670.

Tandi, E.K. 2010. Pengaruh Tanin terhadap Aktivitas Enzim Protease. Seminar Nasional Teknologi Peternakan dan Veteriner, Makassar.

Umeh, S.O., B.N. Emelugo, E.E. Bassey, S.C. Nwobi, dan J.N. Achufusi. 2013. Investigation of the antimicrobial and analgesic activities of crude ethanolic extract of ginger (Zingiber officinale) rhizome. International Journal of Agriculture and Biosciences. 2 (3): 132-135.

Usunobun, U., N.P. Okolie, O.G. Anyanwu, A.J. Adegbegi, dan M.E. Egharevba. 2015. Phytochemical screening and proximate composition of Annona muricata leaves. European Journal of Botany Plant Science and Phytology. 2 (1): 18-28.

Winarno, F. G. 2002. Kimia Pangan dan Gizi. PT. Gramedia Pustaka Utama, Jakarta. 